\title{
PENGEMBANGAN BAHAN AJAR TIK SMP MENGACU PADA PEMBELAJARAN BERBASIS PROYEK
}

\author{
Fauziyah Kariem Aisyi, Siscka Elvyanti, Tjetje Gunawan, Elih Mulyana \\ Program Studi Pendidikan Teknik Elektro \\ FPTK Universitas Pendidikan Indonesia \\ Jl. Dr. Setiabudhi 207 Bandung \\ Email : alfaruq.muslimnegarawan@gmail.com
}

\begin{abstract}
Abstrak: Makalah ini memaparkan hasil penelitian pengembangan bahan ajar pelajaran TIK SMP yang bercirikan pembelajaran berbasis proyek. Tujuan penelitian ini untuk melakukan validasi kelayakan bahan ajar ditinjau dari aspek substansi dan buku sebagai media pembelajaran. Metode digunakan adalah metode information repackaging, yakni mengumpulkan bahan-bahan dari bukubuku teks yang sudah ada dengan memperhatikan standar kompetensi dan kompetensi dasar pada silabus. Pada pengembangannya, buku teks menggunakan karakteristik pembelajaran berbasis proyek. Diharapkan kegiatan pembelajaran dapat berorientasi pada peserta didik, fokus pada pemecahan masalah, menyelesaikan tugas-tugas otentik dan menghasilkan produk pada akhir kegiatan pembelajaran. Hasil penelitian menyimpulkan bahwa isi materi buku ajar sesuai dengan kurikulum tingkat satuan pendidikan, karakteristik pembelajaran berbasis proyek, dan mudah dipahami siswa meski membutuhkan pemahaman ekstra.
\end{abstract}

Kata kunci : bahan ajar, pembelajaran berbasis proyek, TIK.

\begin{abstract}
This paper discusses the development of junior high school's informational technology and information class material that characterizes project-based learning. The research aimed at the subtance validation and feasibility of the teaching materials as learning media. Using information repackaging method, researchers collected materials from the existing textbooks while considering the competence standard and the basic competence as listed in the class syllabus. In their development, the textbooks incorporate project-based learning characteristics. It is expected that learning activities are student-centered, focusing on problem solving and completing authentic tasks as well as creating products in the end of the semester. The study concludes that the book contents are in accordance with the school-based curriculum, the project-based learning characteristics, and are easy to comprehend, despite the need for extra understanding.
\end{abstract}

Keywords : teaching material, project-based learning, ICT

\section{PENDAHULUAN}

Bahan ajar merupakan komponen yang memegang peranan penting dalam proses belajar mengajar. Keberadaan bahan ajar akan membantu pendidik untuk mencapai tujuan pembelajaran dan memenuhi kompetensi dasar. Bahan ajar merupakan salah satu komponen sistem pembelajaran yang memegang peranan penting dalam membantu siswa mencapai Standar Kompetensi dan Kompetensi Dasar atau tujuan pembelajaran yang telah ditentukan (Suparmin \& Pujiastuti, 2010). Suhardjono (2008) dalam makalahnya mengemukakan bahwa bahan ajar 
adalah materi perkuliahan yang disusun secara sistematis yang digunakan dosen dan mahasiswa dalam proses perkuliahan.

Menurut Dikti (2013), yang termasuk ke dalam bahan ajar diantaranya adalah buku, modul dan LKS. Pada penggunaannya, buku yang digunakan dalam dunia pendidikan diantaranya adalah buku teks (Muslich, 2010). Buku teks sendiri merupakan buku yang berisi uraian bahan tentang mata pelajaran atau bidang studi tertentu, yang disusun secara sistematis dan telah diseleksi berdasarkan tujuan tertentu, orientasi pembelajaran, dan perkembangan siswa untuk diasimilasikan (Muslich, 2010). Penelitian ini menitik beratkan pada pengembangan bahan ajar berupa buku teks mata pelajaran Teknologi Informasi dan Komunikasi (TIK) di Sekolah Menengah Pertama (SMP), dengan bercirikan metode pembelajaran berbasis proyek.

Pembelajaran berbasis proyek bertujuan membantu peserta didik untuk mengembangkan kemampuan pada lingkungan yang berbasis pengetahuan dan berteknologi maju, menyiapkan peserta didik untuk dapat menghadapi tantangan dunia hari ini, dan memecahkan masalah yang kompleks yang memungkinkan peserta didik memiliki kemampuan dasar (Division,2006). Pembelajaran berbasis proyek dapat diartikan sebagai model pembelajaran yang bertujuan mendorong peserta didik membangun pengetahuan dan keterampilan siswa secara mandiri, mendorong siswa untuk memecahkan masalah yang berkaitan dengan kehidupan yang nyata. Sehingga mereka akan lebih terbuka pola pikirnya dan puncaknya menghasilkan produk karya siswa bernilai, dan realistik.

Pembelajaran berbasis proyek secara umum memiliki 3 tahapan. Pertama, tahap persiapan, yaitu tahap standar pengantar pembelajaran dimana informasi dan jadwal dibuat. Pada tahap ini, mahasiswa berusaha memahami satu sama lain dengan memperkenalkan diri dan mengumpulkan harapannya di dalam keseluruhan aktifitas proyek. Kedua, tahap proses PBL, yaitu tahapan-utama pembelajaran dan terdiri dari sejumlah aktifitas berkenaan dengan persiapan dan langkah penting pengerjaan suatu proyek. Tahap ini meliputi: (a) pembentukan kelompok dan pemilihan proyek, (b) pengumpulan informasi, dan (c) langkah kerja proyek. Ketiga, tahap evaluasi, Pola ini menunjukan bentuk aktifitas di dalam melakukan penilaian terhadap mahasiswa. Feedback membantu dosen 
dalam menafsirkan penguasaan mahasiswa tehadap proyek yang telah dikerjakannya (Rais, 2010).

Secara umum terdapat tiga cara yang dapat ditempuh dalam menyusun bahan ajar, yaitu (Suparmin, 2010):

a. Menulis sendiri (Starting From Scratch)

Bahan ajar dapat ditulis sendiri oleh guru sesuai dengan kebutuhan siswa. Selain ditulis sendiri guru dapat berkolaborasi dengan guru lain untuk menulis bahan ajar secara kelompok, dengan guru-guru bidang studi sejenis, baik dalam satu sekolah atau tidak. Penulisan juga dapat dilakukan bersama pakar, yang memiliki keahlian di bidang ilmu tertentu. Disamping penguasaan bidang ilmu, untuk dapat menulis sendiri bahan ajar, diperlukan kemampuan menulis sesuai dengan prinsip-prinsip instruksional. Penulisan bahan ajar selalu berlandaskan pada kebutuhan siswa, meliputi kebutuhan pengetahuan, keterampilan, bimbingan, latihan, dan umpan balik. Untuk itu dalam menulis bahan ajar didasarkan: (a) analisis materi pada kurikulum, (b) rencana atau program pengajaran, dan (c) silabus yang telah disusun.

b. Pengemasan kembali informasi (Information Repackaging)

Dalam pengemasan kembali informasi, penulis tidak menulis bahan ajar sendiri dari awal (from scratch), tetapi penulis memanfaatkan buku-buku teks dan informasi yang sudah ada untuk dikemas kembali sehingga berbentuk bahan ajar yang memenuhi karakteristik bahan ajar yang baik, dan dapat dipergunakan oleh guru dan peserta didik dalam proses instruksional. Bahan atau informasi yang sudah ada di pasaran dikumpulkan berdasarkan kebutuhan dan tujuan pembelajaran. Kemudian ditulis kembali/ulang dengan gaya bahasa yang sesuai untuk menjadi bahan ajar (digubah), juga diberi tambahan kompetensi atau keterampilan yang akan dicapai, bimbingan belajar, latihan, tes, serta umpan balik agar mereka dapat mengukur sendiri kompetensinya yang telah dicapai. Keuntungannya, cara ini lebih cepat diselesaikan dibanding menulis sendiri. Sebaiknya memperoleh ijin dari pengarang buku aslinya.

c. Penataan informasi (Compilation atau Wrap Around Text) 
Selain menulis sendiri bahan ajar juga dapat dilakukan melalui kompilasi seluruh materi yang diambil dari buku teks, jurnal, majalah, artikel, koran, dll. Proses ini disebut pengembangan bahan ajar melalui penataan informasi (kompilasi).

Proses penataan informasi hampir mirip dengan proses pengemasan kembali informasi. Namun, dalam proses penataan informasi tidak ada perubahan yang dilakukan terhadap buku teks, materi audio-visual, dan informasi lain yang sudah ada di pasaran. Jadi buku teks, materi audio-visual dan informasi lain tersebut digunakan secara langsung, hanya ditambahkan dengan pedoman belajar untuk peserta didik tentang cara menggunakan materi tersebut, latihanlatihan dan tugas yang perlu dilakukan, umpan balik untuk peserta didik dan dari peserta didik.

\section{METODE}

Penelitian diawali dengan kegiatan pencarian dan pengolahan data mengenai silabus KTSP, sumber pustaka bahan ajar dan literatur pembelajaran berbasis proyek. Dari kegiatan ini, peneliti menemukan standar kompetensi dan kompetensi dasar apa saja yang dibutuhkan dalam pengembangan bahan ajar, mencari dan mengumpulkan pustaka-pustaka yang dapat dijadikan acuan untuk mengembangkan bahan ajar, dan mengetahui karakteristik dari pembelajaran berbasis proyek. Pada tahap pertama ini, peneliti mendapatkan ide mengenai materi-materi apa saja yang dapat dijadikan bahan untuk pengembangan bahan ajar.

Tahap berikutnya, peneliti mulai membuat bahan ajar, tahap ini, tidak dapat dilanjutkan ke tahap berikutnya jika pengembangan bahan ajar belum selesai. jika pembuatan bahan ajar selesai, maka dapat dilanjut ke tahap berikutnya yakni penyusunan instrumen penilaian buku teks. Seperti tahap pembuatan bahan ajar, pada tahap penyusunan instrument ini, tidak dapat dilanjutkan hingga penyusunan instrumen selesai.

Setelah tahap penyusunan instrument selesai, maka akan dilanjut ke tahap berikutnya yakni tahap revisi. Disini, bahan ajar yang sudah selesai dibuat 
diperiksa dan diperbaiki dari segi tata tulis, bahasa, dan konsep pembelajaran berbasis proyek itu sendiri.

Setelah tahap revisi selesai, maka dapat dilanjutkan ke tahap penelitian dilapangan yakni tahap penelitian bahan ajar dengan menggunakan instrument penilaian buku teks. Setelah mendapatkan data hasil penelitian, maka dilakukan analisa dan pembahasan terhadap data yang sudah diperoleh tadi. Setelah melakukan analisa, maka penelitian memasuki tahap akhir, peneliti membuat kesimpulan dari analisa dan pembahasan yang telah dilakukan pada tahap kelima.

Untuk menguji kelayakan bahan ajar yang telah dikembangkan, dilakukan uji pengguna meliputi guru-guru TIK SMP kelas VIII di Kota Subang sebanyak 7 orang, terdiri dari dua guru SMPN 1, dua guru dari SMPN 2, satu guru SMPN 3, dan satu guru dari SMPN 6. Adapun pertimbangan pengambilan sekolah-sekolah tersebut adalah karena menurut pandangan umum masyarakat di kota Subang, keempat sekolah tersebut adalah sekolah favorit karena prestasi sekolah yang dimiliki. Sedangkan pengambilan sampel guru ditentukan oleh kelas guru mengajar.

Keempat sekolah tersebut memiliki perbedaan satu sama lain. Salah satunya dapat dilihat dari aspek fasilitas teknologi yang dimiliki oleh sekolah. Sekolah yang memiliki fasilitas teknologi yang mendukung seperti WiFi dan banyaknya komputer di laboratorium memungkinkan siswa terbiasa dengan teknologi. Keterbiasaan menggunakan teknologi yang difasilitasi sekolah akan berpengaruh terhadap keterbacaan siswa dalam menggunakan buku teks TIK. Siswa yang terbiasa menggunakan teknologi, dianggap lebih cepat mengerti dan memahami isi buku dibandingkan dengan siswa yang tidak terbiasa.

\section{HASIL DAN PEMBAHASAN}

\section{Pencarian Silabus dan Sumber Pustaka}

Pembelajaran berbasis proyek adalah metode pembelajaran yang mana peserta didik mencari sendiri informasi dalam menuntaskan proyek yang sedang ia kerjakan. Oleh karena itu, pada pendesainan bahan ajar ini disusun dengan singkat dan padat. Uraian materi yang lebih sedikit serta singkat bila dibandingkan dengan buku bahan ajar lainnya. Hal ini dapat dilihat pada Bab I 
dan Bab VIII. Pada kedua bab tersebut, materi tidak dibahas secara mendalam karena materi selebihnya dijadikan sebagai bahan proyek untuk peserta didik.

Pengembangan bahan ajar tentunya memiliki satu atau lebih sumber bahan ajar lainnya. Dalam hal ini penggunaan buku TIK SMP kelas VIII karya Henry Pandia dengan penerbit Erlangga menjadi salah satu sumber utama. Alasannya karena buku yang diterbitkan dari penerbit tersebut banyak diminati oleh sekolah. Hal ini pun terbukti ketika terjun ke lapangan, tiga dari empat sekolah yang dijadikan tempat penelitian menggunakan buku tersebut sebagai referensi. Oleh karena itu, tidak mengherankan apabila dalam daftar pustaka diakhir bab lebih sering muncul buku tersebut.

\section{Deskripsi Bahan Ajar yang Dikembangkan}

Bahan ajar yang dikembangkan berupa buku teks setebal 145 halaman. Di dalamnya terdiri dari 13 bab, dengan uraian enam bab mengenai MIcrosoft Word, enam bab mengenai Microsoft Excel dan satu bab mengenai proses mencetak dari dokumen Word dan Excel. Nama-nama bab, dibuat sedemikian rupa berdasarkan pembelajaran berbasis proyek yang memiliki karakteristik memecahkan permasalahan di dunia nyata, studi literatur di beberapa buku teks dan tingkat perkembangan kognitif usia SMP Kelas VIII. Nama-nama bab dibuat sederhana sesuai dengan tujuan pembelajaran yang diinginkan. Berikut ini, nama bab beserta tujuan pembelajaran yang ingin dicapai dan kompetensi dasar yang dipenuhi.

Tabel 1. Tujuan Pembelajaran dan Kompetensi Dasar Buku Teks

\begin{tabular}{|c|c|c|c|c|}
\hline Urutan Bab & Nama Bab & & Tujuan Pembelajaran & $\begin{array}{l}\text { Kompetensi Dasar } \\
\text { yang Dipenuhi }\end{array}$ \\
\hline Bab I & $\begin{array}{l}\text { Berkenalan dengan Perangkat } \\
\text { Lunak Pengolah Kata }\end{array}$ & 2. & $\begin{array}{l}\text { Mengenali tab dan ikon } \\
\text { yang ada pada Microsoft } \\
\text { Word } \\
\text { Mengidentifikasi nama } \\
\text { dan fungsi tab dan ikon } \\
\text { yang ada di Microsoft } \\
\text { Word }\end{array}$ & $\begin{array}{ll}\text { 1. } & \begin{array}{l}\text { Mengidentifikasi } \\
\text { menu dan ikon } \\
\text { pada Perangkat } \\
\text { Lunak Pengolah } \\
\text { Kata (PLPK) } \\
\text { 2. }\end{array} \\
\text { Menjelaskan } \\
\text { fungsi menu dan } \\
\text { ikon pada PLPK }\end{array}$ \\
\hline Bab II & Membuat Dokumen Sederhana & $\begin{array}{l}1 . \\
2 .\end{array}$ & $\begin{array}{l}\text { Membuat dokumen baru } \\
\text { Membuka dokumen } \\
\text { yang sudah disimpan } \\
\text { sebelumnya } \\
\text { Menyimpan dokumen }\end{array}$ & $\begin{array}{ll}\text { 1. } & \text { Menjelaskan } \\
\text { fungsi menu dan } \\
\text { ikon pada PLPK }\end{array}$ \\
\hline
\end{tabular}


Bab III

Bab IV

Bab V

Bab VI

Bab VII

Bab VIII

Bab IX

Bab X
Mengelola Dokumen

Membuat Dokumen Berkolom

Membuat surat dan menyisipkan nomor halaman

Membuat dokumen berumus dan bersimbol

Menyisipkan dan mengedit gambar

Berkenalan dengan perangkat lunak pengolah angka

Membuatsebuah lembar kerja

Mengolah data menggunakan rumus dan fungsi

3. Membuat dokumen PLPK sederhana

1. Mengatur format halaman

2. Mengatur format paragraf

1. Membuat dokumen berkolom

1. Menyisipkan header

2. Menyisipkan footer

3. Menyisipkan halaman

1. Menyisipkan rumus

2. Menyisipkan simbol

1. Menyisipkan gambar

2. Mengedit gambar

1. Mengenali tab dan ikon yangada di Microsoft Excel

2. Mengidentifikasi nama dan fungsi yang ada di Microsoft Excel

1. Membuat lembar kerja baru

2. Membuka lembar kerja yang sudah disimpan

3. Menyimpan lembar kerja

1. Mengolah angka menggunakan rumus

2. Mengolah angka menggunakan fungsi
1. Menggunakan menu dan ikon pokok pada PLPK

2. Menggunakan menu dan ikon pokok pada PLPK

3. Membuat dokumen PLPK sederhana

1. Menggunakan menu dan ikon pokok pada PLPK

2. Membuat dokumen PLPK sederhana

1. Menggunakan menu dan ikon pokok pada PLPK

2. Membuat dokumen PLPK sederhana

1. Menggunakan menu dan ikon pokok pada PLPK

2. Membuat dokumen PLPK sederhana

1. Mengidentifikasi menu dan ikon pada Perangkat Lunak Pengolah Angka (PLPA)

2. Menjelaskan fungsi menu dan ikon pada PLPA

1. Menggunakan menu dan ikon pokok pada PLPA

2. Membuat dokumen PLPA sederhana

1. Menggunakan menu dan ikon pokok pada PLPA

2. Membuat 
Bab XI

Bab XIII
Mengurutkan dan menyaring data

Menyisipkan grafik pada lembar kerja
1. Mengurutkan data

2. Menyaring data

1. Menyisipkan grafik

2. Mengedit grafik

1. Mencetak dari dokumen Ms Word dan Ms Excel dokumen PLPA sederhana

1. Menggunakan menu dan ikon pokok pada PLPA

2. Membuat dokumen PLPA sederhana

1. Menggunakan menu dan ikon pokok pada PLPA

2. Membuat dokumen PLPA sederhana

1. Menggunakan menu dan ikon pokok pada PLPA

\section{Hasil Uji Kelayakan}

Menurut BSNP, buku yang berkualitas wajib memenuhi empat unsur kelayakan yakni kelayakan isi, kelayakan penyajian, kelayakan kebahasan, dan kelayakan kegrafikaan. Kelayakan isi menurut BSNP mengacu pada Permendiknas No. 2 Tahun 2008 yakni harus memenuhi tiga indikator: (1) Kesesuaian uraian materi dengan Standar Kompetensi dan Kompetensi Dasar, (2) Keakuratan materi, (3) Materi pendukung pembelajaran.

Berdasarkan hasil pengolahan instrumen berkaitan dengan kesesuaian uraian materi dengan SK dan KD maka didapatkan bahwa keluasan materi yang dimiliki buku teks sudah sesuai dengan Standar Kompetensi dan kedalaman materi yang dimiliki buku teks sudah sesuai dengan Kompetensi Dasar. Dari aspek akurasi, sebagian besar responden setuju bahwa buku teks akurat sesuai dengan kenyataan (fakta) dan konsep yang berlaku pada bidang TIK, mampu mencapai tujuan pembelajaran dan tidak menimbulkan banyak tafsir. Ilustrasi yang digambarkan sesuai dengan fakta, konsep dan efisien untuk meningkatkan pemahaman peserta didik, sehingga tidak membuat siswa memahami secara verbalistis.

Penilaian kelayakan menggali juga pendapat responden tentang materi pendukung pembelajaran. Responden diminta untuk menilai kesesuaian materi dengan perkembangan ilmu pengetahuan, rujukan, contoh serta fitur yang 
kekinian, dan ke-kontekstual-an materi yang dikembangkan pada buku teks. Sebanyak $83,3 \%$ responden setuju bahwa materi yang tercantum pada buku teks sesuai dengan perkembangan ilmu. Sebanyak 83,3\% responden setuju bahwa rujukan, contoh serta fitur yang digunakan pada buku teks telah mengikuti perkembangan teknologi (ke-kini-an). Untuk aspek kontektual, enam responden, empat orang menilai setuju, satu orang menilai ragu-ragu dan sisanya satu orang sisanya abstain (error). Hal ini bisa disebabkan dua kemungkinan. Kemungkinan pertama, responden memang abstain dan kemungkinan yang kedua, responden lupa mengisi angket pada butir ini. Meski begitu, dapat disimpulkan bahwa 67,7\% responden setuju bahwa materi pendukung pembelajaran pada buku teks dinilai kontekstual, maksudnya berasal dari lingkungan terdekat dan akrab dengan kehidupan sehari-hari. Sehingga peserta didik mudah untuk memahami pesan yang disampaikan dan mudah untuk menyadari aplikasi materi dalam kehidupan sehari-hari.

Berkaitan dengan penilaian kesesuaian isi buku dengan tahapan pembelajaran berbasis proyek, responden diminta untuk menilai kesesuaian isi buku dengan tahapan pembelajaran berbasis proyek yang memiliki beberapa karakteristik seperti mengedepankan proyek dalam pembelajaran, mewakili pemecahan masalah di dunia nyata, mendorong peserta didik untuk mendesain sendiri produk yang akan dikerjakan, dan terdorong untuk mengembangkan kompetensinya. $83,3 \%$ responden setuju bahwa materi pada buku teks mengedepankan proyek dan evaluasi yang digunakan mampu mewakili pemecahan masalah di dunia nyata. Seluruh responden setuju bahwa dengan belajar melalui buku teks, peserta didik terdorong untuk mendesain sendiri produk yang akan dikerjakan. Seluruh responden setuju bahwa dari proyek yang ditugaskan, peserta didik terdorong untuk mengembangkan kompetensinya.

\section{Pendapat Guru Mengenai Isi dan Struktur Buku}

Pada bagian ini, responden diminta untuk menilai beberapa indikator mengenai isi dan struktur buku. Indikator yang dicantumkan diadaptasi dari instrumen penilaian buku teks BSNP. Dalam instrumen 2 penilaian buku teks BSNP pelajaran mendeskripsikan bahwa materi yang sesuai dengan tingkat 
berpikir peserta didik yakni "materi disajikan dengan bahasa yang sederhana, menarik, lugas dan mudah dipahami". sebanyak 67,7\% responden setuju bahwa materi yang tercantum pada buku teks, sesuai dengan tingkat berpikir siswa.

Dalam instrumen 2 penilaian buku teks BSNP pelajaran mendeskripsikan bahwa materi yang sesuai dengan perkembangan sosial emosional peserta didik adalah:

" bahasa yang digunakan sesuai dengan kematangan sosial emosional peserta didik, sehingga menimbulkan rasa senang pada peserta didik dan mendorong mereka unntuk mempelajari buku secara tuntas. Contoh, soal dan latihan menggunakan kalimat mengajak bukan menyuruh atau memerintah"

Dari keenam responden, sebanyak dua orang menilai sangat setuju, satu orang menilai setuju dan tiga orang lainnya menilai ragu-ragu terhadap kesesuaian materi dengan perkembangan sosial emosional peserta didik. Perbedaan pendapat yang merata mungkin masih disebabkan oleh kondisi peserta didik yang berbeda tiap sekolah.

Dalam instrumen 2 penilaian mencantumkan indikator penilaian "berpusat pada peserta didik" yang memiliki uraian: "penyajian materi dalam buku bersifat interaktif dan pertisipatif sehingga memotivasi peserta didik untuk belajar mandiri”. Sejalan dengan pembelajaran berbasis proyek, yang menganut teori belajar konstruktivisme yang mana melatih dan mendidik peserta didik untuk membangun pengetahuannya sendiri, mencari informasi sehingga mampu memecahkan masalah di dunia nyata. Dari enam responden, satu orang menilai ragu-ragu dan lima orang menilai setuju. Artinya 83,3\% responden setuju bahwa penyajian materi bersifat interaktif

Dalam instrumen 2 penilaian buku teks BSNP pelajaran mendeskripsikan bahwa:

"penyajian dan pembahasan dalam buku teks lebih menekankan pada keterampilan proses (berpikir dan psikomotorik) sesuai dengan kata kerja operasional pada SK dan KD, bukan hanya pada perolehan hasil akhir."

Evaluasi atau umpan balik yang dituntut kepada siswa tidak hanya pada tugas akhirnya melainkan proses pembuatan tugasnya tersebut. Dari enam responden, satu orang menilai sangat setuju dan sisanya lima orangmenilai setuju. Artinya, seluruh responden setuju bahwa penyajian dan pembahasan materi pada buku teks lebih menekankan pada keterampilan proses 
Variasi dalam teknik penyajian sangat dibutuhkan untuk menghindari kejenuhan peserta didik dalam membaca. Hal serupa juga pada instrumen 2 BSNPyang secara tersirat menginginkan adanya variasi dalam penyajian materi agar tidak membosankan, misalnya deduktif (umum ke khusus), induktif (khusus ke umum), begitu pula dengan penggunaan berbagai ilustrasi seperti gambar, foto, grafik dan tabel). Dari enam responden sebanyak satu orang menilai sangat setuju dan lima orang sisanya menilai setuju. Artinya, seluruh responden setuju bahwa penyajian proyek bervariasi sehingga tidak akan membuat bosan peserta didik.

Berikutnya, responden diminta untuk menilai kelengkapan penyajian dimulai dari pendahuluan, daftar isi, daftar pustaka, ilustrasi yang digambarkan dan soal evaluasi di akhir bab. Seluruh responden setuju bahwa buku teks menarik minat pembaca, buku teks memiliki daftar isi sebagai kelengkapan sebuah buku dan $83,3 \%$ responden menilai setuju bahwa buku teks yang dikembangkan memiliki kelengkapan berupa daftar pustaka.

Karena pengembangan bahan ajar ini menggunakan pembelajaran berbasis proyek, maka soal evaluasi latihan direkayasa sesuai dengan tahapan pembelajaran berbasis proyek. Sehingga seluruh soal evaluasi berupa kerja praktek. Sebanyak tiga orang responden menilai sangat setuju, dua orang lainnya menilai setuju dan sisanya satu orang menilai ragu-ragu. Artinya, 83,3\% responden setuju bahwa terhadap proyek yang ditugaskan, ia menyarankan sebaiknya ada soal evaluasi secara materi tertulis agar dapat mendukung tugas praktik.

Tahapan berikutnya guru memberikan pendapat terkait proporsi gambar dan teks yang tepat. Menurut Muslich (238:2009), perbandingan gambar dan teks yang digunakan harus benar-benar dapat menjelaskan gagasan yang disampaikan secara verbal, menarik siswa serta mudah untuk dipahami. Pada sumber yang sama, Muslich (311:2009) menyatakan bahwa, tidak terlalu banyak menggunakan jenis huruf hias/dekoratif karena akan mengurangi tingkat keterbacaan susunan teks. Sedangkan BSNP menyatakan, proporsi gambar dan teks disesuaikan dengan tingkat kepahaman peserta didik. Selain itu pula, proporsi gambar dan teks harus tepat disesuaikan dengan materi atau pesan yang akan disampaikan. Karena gambar bisa membantu menyampaikan pesan yang tertera dalam teks, begitu pula 
sebaliknya. Dari keenam responden, sebanyak dua orang menilai sangat setuju,tiga orang menilai setuju dan sisanya sebanyak satu orangmenilai raguragu. Artinya, 83,3\% responden setuju bahwa buku memiliki ketepatan proporsi dan gambar.

\section{KESIMPULAN}

Buku teks sudah sesuai dengan KTSP, hal ini tercermin dari keluasan dan kedalaman materi sesuai dengan Standar Kompetensi dan Kompetensi Dasar KTSP. Buku teks juga memiliki karakteristik yang dimiliki oleh metode pembelajaran berbasis proyek yang mengedepankan proyek dalam pembelajaran, proyek yang diberikan mewakili tantangan kehidupan sehari-hari, mendorong peserta didik untuk lebih inovatif dan kreatif dalam merancang sendiri rencana kerjanya. Buku teks memiliki kerunutan konsep dalam penulisan, ilustrasi yang mendukung pesan, materi yang bersifat interaktif, mengedepankan proyek, dan proyek yang bervariatif, sehingga buku teks ini dapat menarik minat baca dan memicu peserta didik untuk dapat belajar mandiri.

\section{DAFTAR PUSTAKA}

Muslich, M. (2010). Text Book Writting: Dasar-dasar Pemahaman, Penulisan, dan Pemakaian Buku teks. Jogjakarta: Ar-Ruzz Media.

Suparmin, \& Pujiastuti, D. (2010). Pengembangan Bahan Ajar. Jambi: Program Magister Teknologi Pendidikan Pascasarjana Universitas Jambi.

Suhardjono. (2008). Menyusun Bahan Ajar Agar Tujuan Perkuliahan Tercapai Lebih Menyenangkan. Malang: Jurusan Sipil Fakultas Teknik Universitas Brawijaya.

Division, E. T. (2006). Project-Based Learning Handbook. Kuala Lumpur: Malaysia Ministry of Education.

Rais, M. (2010). Project-Based-Learning: Inovasi Pembelajaran yang Berorientasi Soft Skill. Seminar Nasional Pendidikan Teknologi dan Kejuruan Fakultas Teknik Universitas Negeri Surabaya. Surabaya: Universitas Negeri Makasar.

Ruenglertpanyangkul, W., Vicheanpant, T., Chanchaona, S., \& Nantawisarakul, T. (2012). The Project Based Learning for Develoop Student's Literacy and Working Skill in Rural School. European Journal of Social Sciences, 518-531. 